\title{
ArcheoSciences
}

Revue d'archéométrie

\section{A case study the necropole area of Antandros ancient city (Turkey) by magnetic prospection}

\section{Melda Küçükdemirci}

\section{(2) OpenEdition}

1 Journals

Electronic version

URL: https://journals.openedition.org/archeosciences/1747

DOI: 10.4000/archeosciences. 1747

ISBN: 978-2-7535-1599-4

ISSN: 2104-3728

Publisher

Presses universitaires de Rennes

\section{Printed version}

Date of publication: 30 October 2009

Number of pages: $303-304$

ISBN: 978-2-7535-0943-6

ISSN: $1960-1360$

\section{Electronic reference}

Melda Küçükdemirci, "A case study the necropole area of Antandros ancient city (Turkey) by magnetic prospection", ArcheoSciences [Online], 33 (suppl.) | 2009, Online since 30 October 2011, connection on 01 February 2022. URL: http://journals.openedition.org/archeosciences/1747 ; DOI: https://doi.org/ 10.4000/archeosciences. 1747 


\title{
A case study the necropole area of Antandros ancient city (Turkey) by magnetic prospection
}

\author{
Melda KüÇÜKDEMIRCI*
}

Key words: Magnetic prospection, Archaeology, Antandros, Data processing, Euler deconvolution.

The aim of this study is to investigate by magnetic prospection ancient structures buried in the necropolis of the historically and archaeologically important city of Antandros in Altınoluk, Balıkesir (Turkey). Antandros is a city in Troas, located on the hillside of İda Mountain. Archaeological excavations started in a part of the city in 2001 have brought to light Late Roman and Hellenistic remains.

The present magnetic study focused on an area believed to be the necropolis of ancient Antandros.

Magnetic measurements were collected with a Scintrex Proton magnetometer from a gridded study area. Magnetic field corrections were applied to the magnetic data which were affected by diurnal magnetic fields. To separate regional and residual anomalies, filters, continuations and derivative techniques were applied (Fig. 2). To detect the boundaries of features, boundary analysis was used.

For modelling potential structures the Talwani method was applied taking into consideration the results of an Euler deconvolution to determine the shapes, depths and elongation of relics. In the modelling process, two different artificial models were created to understand the Euler deconvolution principles by choosing window size and the structural index parameter. This was then applied to the field data. For the Talwani modelling,the susceptibility of the relics was measured by a Bartington Ms2 B probe. For the data

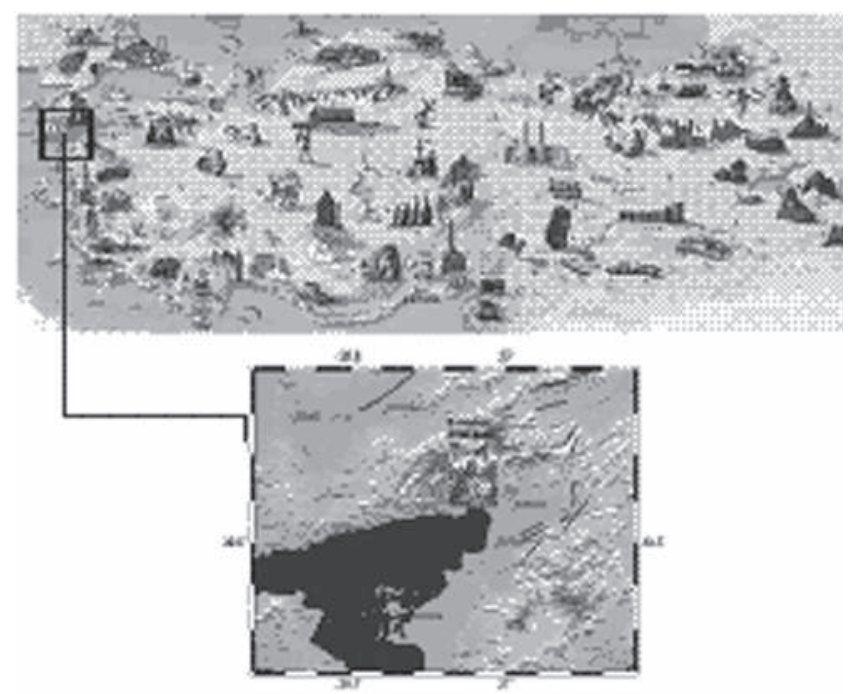

Figure 1: Study location on the archaeological map of Turkey.

processing and modelling techniques, PF Potential-Field Geophysical Software for the PC, version 2.2 (Phillips,1997) and MAGPICK Version 2 (Tchernychev,1998) programmes were used.

According to the data processing and modelling results of this study and the distribution and shape of subterranean

* Department of Geophysical Engineering, Istanbul University, Istanbul,Turkey. (meldakd@istanbul.edu.tr) 


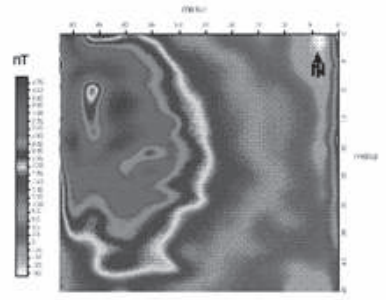

a) Low pass filter

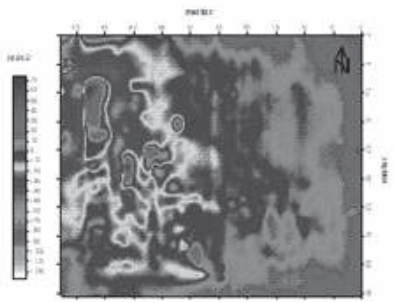

b) Second vertical derivative

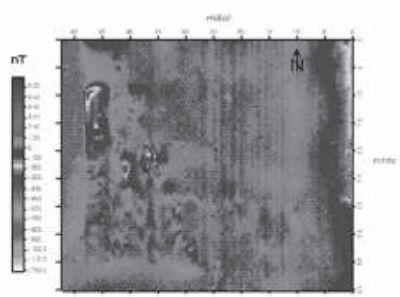

Figure 2 (see color plate): Magnetic data processing results.

graves, the main anomaly can be seen between the 25th and 50 th meter along the horizontal axis of the magnetic map. It could mean that the graves do not extend beyond the 25 th meter. On the other hand, it could mean that there is an ancient road separating the necropolis from the Roman settlement. An ancient road running from west to east was recorded previously in archaeological excavations. To investigate these possibilites, a test excavation 20 by $2 \mathrm{~m}$ is suggested, at least $1.5 \mathrm{~m}$ deep, to be dug between the 30 th and 50 th meters on the horizontal axis, oriented from northeast to southwest.

Thanks are due Prof. Niyazi Baydemir and Assoc. Prof. Z. Mümtaz Hisarlı from the Istanbul University Geophysical Engineering Department for their advice. We would also liek to acknowledge the help of Assoc. Prof. Gürcan Polat from the Aegean University, Department of Archaeology, for providing us with the sources we used.

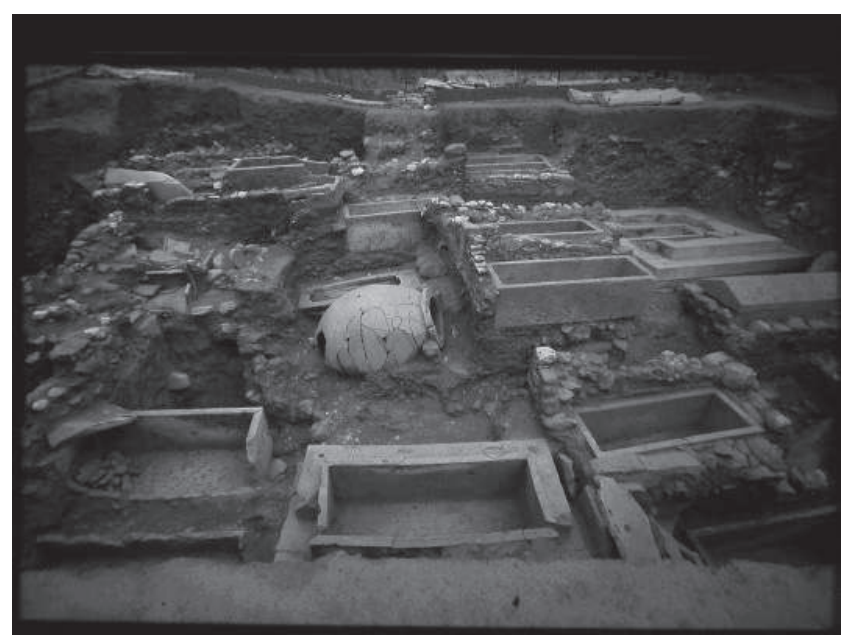

Figure 3: Excavated part of the necropolis area.

\section{References}

Phillips, J. D., 1997. Potential-Field Geophysical Software for the PC, Version 2.2.U.S.Geological Survey, Open-File Report, 97-725.

TChernychev, M.,1998. Magpick-Magnetic Map and Profile Processing User Guide. 